N. Yu. NAUMENKO, V. B. SOBOLEVSKA, O. M. MARKOVA, H. N. KOVTUN, D. V. HOROBETS, V. V. MALIY, S. A. SYROTA, I. YU. KHIZHA

\title{
SOLUTIONS TO THE PROBLEMS OF RAILWAY TRANSPORTATION SAFETY IMPROVEMENT AND PASSIVE PROTECTION OF A PASSENGER TRAIN IN EMERGENCY COLLISIONS
}

\author{
Institute of Technical Mechanics \\ of the National Academy of Sciences of Ukraine and the State Space Agency of Ukraine \\ 15 Leshko-Popel St., 49005,Dnipro, Ukraine; e-mail: dep7@ukr.net
}

The priority tasks of the Ukrainian railway transport are a train speed increase, passenger car renewal and safe operation, and the passive protection of passenger trains in their emergency collisions with obstacles. An integral part of high-speed passenger cars of new generation must be passive safety systems (PSSs), which operate in an emergency collision. The controllable deformation of the PSS energy- absorbing devices (EADs) reduces the longitudinal forces and accelerations, which makes it possible to save the lives of the passengers and the train crew, reduce damage to the cars, and minimize the consequences of the accident. In the EU countries, the mandatory installation of PSSs is required by Standard EN 15227. A similar standard is adopted in Ukraine, too, despite the fact that the couplers used in Ukraine differ considerably in design from those used in the EU countries. This paper addresses the problem of elaboration of a scientific basis for the development of collision PSSs for the cars of high-speed passenger trains operating on the Ukrainian railways and the problem of determination of factors that affect car derailment in a collision. An algorithm, methods, and finite-element models for choosing the EAD design parameters were developed and validated by a crash test of a prototype locomotive EAD. A mathematical model was developed to study the dynamics of PSS-equipped trains, to determine longitudinal and vertical loads on the car structures, and to assess the required EAD energy absorption capacity in normative collision scenarios. Comprehensive investigations were conducted, as a result of which locomotive and car EADs were designed. When considering a passenger train - obstacle collision, a separate problem is the determination of factors causing locomotive and car derailment. Such investigations were conducted using a mathematical model developed to describe the spatial oscillations of a moving train whose locomotive is equipped with a passive safety system and anti-climbing devices. When a train moving on a real track with irregularities of different types collides with the obstacle, lateral forces of car-car interaction are produced. This, in its turn, results in lateral forces of wheel-rail interaction, thus considerably affecting the locomotive derailment stability. The calculations conducted by the model showed that the locomotive derailment probability increases with the mass of the obstacle rail vehicle, the train speed at the collision instant, and the level of rail irregularities. The results of the investigations conducted may be used in designing a new generation of high-speed passenger trains.

Keymords railway traffic safety, passenger train - obstacle collision, passive safety system, energy-absorbing device, mathematical simulation, spatial oscillations, derailment.

1. EN 15227. Railway applications - Crashworthiness requirements for railway vehicle bodies. Brussels, 2008. $37 \mathrm{pp}$.

2. Catalog of Normative Documents (in Ukrainian). URL: http://uas.org.ua/ua/natsionalniy-fond-normativnihdokumentiv/katalog-normativnih-dokumentiv-2/ (Last accessed: April 24, 2018).

3. Sobolevskaya M. B., Sirota S. A. Basic concepts of passive safety of high-speed passenger trains at crash collisions (in Russian) .Teh. Meh. 2015. No. 1 Pp. 84-96.

4. Sobolevska M. B., Telychko I. V., Syrota S. A., Khruchsh I. K., Horobets D. V., Klyk Yu. A. Mathematical simulation of the elastoplastic deformation of the energy-absorbing elements of a locomotive passive safety system in an emergency collision with an obstacle (in Russian). Teh. Meh. 2010. No. 4. Pp. 75-85.

5. Sobolevska M., Telychko I. Passive safety system of an electric locomotive for high-speed operation on the railways with $1520 \mathrm{~mm}$ gauge. Passive Safety 2013 - Passive Safety of Rail Vehicles and Safe Interiors. Proceedings of the 9th International Symposium (21 - 22 February 2013, Berlin). Berlin, 2013. Pp. 63-80.

6. Sobolevska M., Telychko I. assive safety of high-speed passenger trains at accident collisions on $1520 \mathrm{~mm}$ gauge railways. Transport Problems. 2017. V. 12. Issue 1. p. 51-62.

7. Krieg R. D., Key S. W. Implementation of a time independent plasticity theory into structural computer programs. Vol. 20 of Constitutive equations in viscoplasticity: computational and engineering aspects. New York: ASME, 1976. p. 125-137.

8. Symonds P. S. Dynamics of Inelastic Structures (in Russian). Moscow. : Mir, 1982. 224 pp.

9. Cowper G. R., Symonds P. S. Strain Hardening and Strain Rate Effects in the Impact Loading of Cantilever Beams. Providence : Brown University, 1958. P. 46.

10. Oden J. Finite Elements of Nonlinear Continua (in Russian). Moscow : Mir, 1976. 464 pp. 
11. Sobolevska M. B., Horobets D. V., Syrota S. A. Determination of the characteristics of obstacles for normative scenarios of passenger train - obstacle collisions (in Russian). Teh. Meh. 2018. No. 2. Pp. 90-103.

12. Sobolevskaya M. B., Sirota S. A., Gorobets D. V., Telichko I. V. Full-scale tests of prototype of energyabsorbing device for passive protection of locomotive at collision (in Russian). Teh. Meh. 2016. No. 2. Pp. 91-105.

13. Naumenko N. Yu., Sobolevska M. B., Khizha I. Yu. Estimation of dynamic loads on a reference train with a passive safety system in its collisions with an identical train and a freight car (in Russian). Teh. Meh. 2017. No. 3. Pp. 72-83.

14. Naumenko N. Ye., Sobolevskaya M. B., Gorobets D. V., Bogomaz Ye. G. Development of elements of passive safety for new-generation high-speed passenger locomotives at emergency collisions on railways with 1520 mm gauge (in Russian). Teh. Meh. 2017. No.1. Pp. 72-82.

15. Naumenko N. Ye., Sobolevskaya M. B., Sirota S. A., Gorobets D. V. Development of passive safety elements for new-generation coaches operating on railways with $1520 \mathrm{~mm}$ gauge (in Russian). Teh. Meh. 2017. No. 2. Pp. 73-83.

16. Markova O., Kovtun H., Maliy V. Modelling train motion along arbitrary shaped track in transient regimes. IMechE Part F: J. Rail and Rapid Transit. 2015. No. 229(1). Pp. 97 - 105.

17. Markova O. M., Kovtun H. N., Maliy V. V. Determination of locomotive derailment stability conditions in emergency collisions (in Russian). Teh. Meh. 2018. No. 2. Pp. 103-112.

Received on August 7, 2018, in final form on September 25, .2018 